\title{
Tetap Produktif dengan Mengembangkan Literasi di Masa Pandemi
}

\author{
Aldha Naila Rahmadani* \\ E-mail: aldhanaila0312@ gmail.com \\ Program Studi Pendidikan Bahasa dan Sastra Indonesia, Univwrsitas Riau
}

\section{Pengantar}

Perkembangan zaman yang semakin maju menuntut manusia untuk selalu berperan aktif menambah ilmu pengetahuan dari berbagai sumber. Berbagai ilmu pengetahuan salah satunya ilmu berbahasa. Kemampuan berbahasa memegang peranan sangat penting. Kemampuan berbahasa salah satunya yaitu literasi.

Di masa-masa pandemi seperti sekarang hampir membuat segala aktivitas kita dilakukan secara dalam jaringan (daring). Meskipun demikian kita harus tetap produktif dan jangan bermalas-malasan. Pandemi bukan penghalang kita untuk tidak produktif, bahkan banyak hal yang bisakita lakukan meskipun segala aktifitas dilakukan di dalam jaringan.

\section{Produktif}

Produktif adalah suatu aktivitas yang mampu menghasilkan suatu hal atau manfaat dari apa yang dikerjakan. Senada dengan pendapat Umi (dalam Sinungan (2008:3), mengemukakan bahwa kerja produktif memerlukan keterampilan kerja yang sesuai dengan isi kerja sehingga bisa menimbulkan penemuan-penemuan baru untuk memperbaiki cara kerja atau minimal mempertahankan cara kerja yang sudah baik. Sedangkan Triton (2010:84), mengemukakan pendapatnya bahwa produktivias mengikutsertakan pendayagunaan secara terpadu sumber daya manusia dan keterampilan, barang modal, teknologi, manajemen informasi energi, dan sumber-sumber lain menuju kepada pengembangan dan peningkatan standar hidup untuk seluruh masyarakat melalui produktivitas total.

Dengan demikian produktivitas terpadu dicapai dengan menentukan tujuan yang efektif, pembuatan rencana, aplikasi penggunaan cara yang produktif untuk 
menggunakan sumber daya-sumber daya secara efisien dan tetap menjaga adanya kualitas yang tinggi.

\section{Literasi}

Literasi adalah istilah umum yang merujuk kepada seperangkat kemampuan dan keterampilan individu dalam membaca, menulis, berbicara, menghitung dan memecahkan masalah pada tingkat keahlian tertentu yang diperlukan dalam kehidupan sehari-hari. Sehingga, literasi tidak bisa dilepaskan dari kemampuan berbahasa. Dengan demikian, literasi tidak hanya diartikan sebagai membaca dan menulis melainkan literasi juga merupakan kemampuan untuk mengidentifikasi, menentukan, menemukan, mengevaluasi, menciptakan secara efektif dan terorganisasi menggunakan dan mengkomunikasikan informasi untuk mengatasi berbagai persoalan. Kebanyakan orang masih belum sadar dengan dunia literasi dan beranggapan bahwa literasi hanya focus pada baca dan tulis sehingga mereka tidak mengerti apa yang dimaksud dengan literasi.

Menurut Kharizmi (dalam Mustafa, 2014) penelitian mengenai pemerolehan literasi cenderung terbagi ke dalam dua kategori umum: perkembangan literasi dini (emergent) dan pelatihan literasi formal. Wardana dan Zamzam (2014) juga menyebutkan berbagai macam pengertian literasi yang telah dikemukakan mengharuskan kita untuk memahami satu per satu guna menarik benang merah dari arti literasi yang bisa kita pahami dengan mudah. Pada awalnya, literasi dimaknai sebagai suatu keterampilan membaca dan menulis, tetapi dewasa ini pemahaman tentang literasi semakin meluas maknanya. Pemahaman terkini mengenai makna literasi mencakup kemampuan membaca, memahami, dan mengapresiasi berbagai bentuk komunikasi secara kritis, yang meliputi bahasa lisan, komunikasi tulis, komunikasi yang terjadi melalui media cetak atau pun elektronik

Literasi sangatlah penting untuk meningkatkan sumber daya manusia yang berkualitas. Apalagi dalam dunia pendidikan yang memberikan dampak terbesar untuk kemajuan bangsa. Dengan kemajuan teknologi saat ini memungkinkan 
seseorang mendapat informasi ataupun ilmu pengetahuan dengan sangat mudah dari berbagai media. Hal tersebut akan memunculkan tantangan-tantangan yang tidak dapat dihindari bagi setiap Negara. Salah satunya Indonesia yang memiliki tingkat literasi yang rendah. Kebanyakan orang Indonesia sendiri lebih suka menatap layar gawai berjam-jam dengan segala aktifitas di dunia maya dibandingkan membaca buku. Bahkan mungkin orang Indonesia hanya membaca satu atau dua buku dalam setahun.

\section{Pengembangan Literasi di Masa Pandemi}

Masa pandemi merupakan masa-masa sulit bagi setiap orang. Cara hidup dan gaya hidup pun berubah. Semua harus mematuhi protokol kesehatan yang sudah diatur oleh pemerintah agar kasus covid-19 menurun. Sayangnya, hingga saat ini masih banyak orang yang membandel dan tidak mematuhinya. Meskipun demikian pemerintah dan maasyarakat yang sadar akan bahayanya tidak tinggal diam dan terus berusaha semaksimal mungkin agar covid-19 segera hilang. Salah satu caranya adalah tetap di rumah dan meminimalisasikan kegiatan yang berada di luar rumah.

Berbagai kebijakan muncul akibat adanya Covid-19. Aktivitas pendidikan dan pembelajaran menjadi persoalan besar sebab ada banyak aktivitas yang tidak cukup secara teoritis tetapi juga praktis. Keadaan ini mengubah tindakan yang semestinya dilakukan secara langsung atau bertatap muka antara pendidik dan peserta didik terhenti dan terbatas. Penelitian Allo (2020) selama aktivitas mendukung, kegiatan belajar bisa berlangsung dengan baik. Sebaliknya, perangkat yang tidak memadai dapat memberikan pengaruh yang buruk terhadap hasil belajarnya. Artinya pendidik maupun peserta didik harus memfasilitasi dirinya agar bisa mengikuti dan melaksanakan pembelajaran secara daring (Zulhafizh, Silvia Permatasari, 2020:938).

Zulhafizh dan Silvia Permatasari (20200 juga menyebutkan bahwa kondisi ini mengubah tatanan cara belajar peserta didik dan para pendidik. Mereka harus memutar arah dari tradisional ke modern agar proses pembelajaran bisa tetap 
berlangsung walaupun dalam kondisi pandemi covid 19. Mengingat kegiatan belajar yang tidak berada dalam satu ruang atau tempat membuat keterbatasan untuk melihat dan mengamati kegiatan belajar peserta didik.

Peristiwa ini banyak membuat peserta didik menjadi malas dan lebih mementingkan gawainya. Maka dari itu perlu pengawasan dan motivasi dari orang-orang sekitarnya agar tetap produktif di masa-masa saat sekarang ini. Menurut Prayitno dan Amti (dalam Zulhafizh, dkk) menjelaskan bahwa hasil belajar sebagai alat untuk mengungkapkan sejauh mana siswa telah mencapai tujuan-tujuan pembelajaran yang telah ditetapkan sebelumnya. Hasil belajar ini menunjukkan perlu atau tidaknya bimbingan terhadap siswa yang kurang berhasil. Keberhasilan siswa dalam belajar dapat diketahui dari nilai-nilai yang diperolehnya, baik secara kognitif, psikomotor, maupun secara afektif.

Produktif di masa pandemi dengan terus meningkatkan literasi merupakan tantangan tersendiri. Namun, banyak hal yang bisa kita lakukan untuk terus meningkatkan literasi. Misalnya, saat di rumah dan melakukan aktivitas pembelajaran di rumah tentu tidak dapat dipungkiri banyak juga waktu luang yang bisa dimanfaatkan. Seperti penulis yang memanfaaatkan waktu-waktu luang untuk berjualan makanan secara online. Penulis menjual Dimsum Literasi, mengapa dinamakan demikian? Karena penulis menyisipkan padanan kata dan istilah di stiker merek produk. Tentunya hal tersebut secara tidak langsung membuat wawasan konsumen bertambah. Banyak hal yang bisa kita lakukan untuk meningkatkan literasi di masa pandemi sekarang. Berbicara di depan kamera juga merupakan pengembangan literasi. di era serba digital sekarang sangat mudah untuk mengenbangkan hal tersebut.

\section{Pentup}

Literasi tidak melulu tentang membaca buku, banyak hal yang bisa kita lakukan untuk mengembangkan literasi di masa-masa pandemi. Literasi merupakan kegiatan yang bisa dilakukan seperti membaca, menulis, berbicara, 
menghitung dan memecahkan masalah. Di era digital sekarang sangat mudah untuk mengembangkan literasi.

\section{Referensi}

Cholis, N. U. (2013) Pengaruh Pelatihan Karyawan Terhadap Produktivitas Kerja Di Pt. Pacific Indo Packing Surabaya. Jurnal Administrasi Perkantoran (JPAP) 1 (3), 2013.

Kharizmi, Muhammad. 2015. Kesulitan Siswa Sekolah Dasar dalam Meningkatkan Kemampuan Literasi. Jupendas, ISSN 2355-3650, Vol. 2, No. 2, September 2015

Musthafa, Bachrudin. 2014. Literasi Dini dan Literasi Remaja: Teori, Konsep, dan Praktik. Bandung: CREST.

Wardana dan Zamzam. 2014. Strategi Peningkatan Kemampuan Literasi Siswa di Madrasah. Jurnal Ilmiah "Widya Pustaka Pendidikan”. 2 (3), hlm. 248-258.

Zulhafizh, dkk. 2013. Kontribusi Sikap dan Motivasi Belajar Siswa Terhadap Hasil Belajar Bahasa Indonesia. Jurnal Bahasa, Sastra, dan Pembelajaran, Volume 1 Nomor 2, Juni 2013.

Zulhafizh dan Silvia Permatasari. 2020. Membina Kualitas Belajar di Masa Pandemi Covid-19Melalui Sikap Berpikir Kreatif dan Kritis. Jurnal PAJAR (Pendidikan dan Pengajaran), Volume 4 Nomor 5 September 2020. 
*Data Penulis

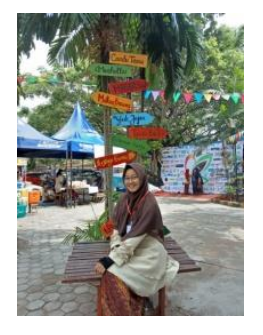

Aldha Naila Rahmadani, lahir 3 Mei 2000 di desa Cikampak kecamatan Torgamba kabupaten Labuhan Batu Selatan provinsi Sumatra Utara. Anak kelima dari enam bersaudara ini lahir dengan keluarga yang tumbuh dengan kasih sayang dan kesederhanaan.

Ia tamat dari SMA pada tahun 2018 dan melanjutkan pendidikan ke PTN. Ia mencoba jalur undangan dan mendaftar di dua universitas negeri yaitu Universitas Riau dan Universitas Negeri Padang dengan jurusan yang sama yaitu Pendidikan Bahasa dan Sastra Indonesia. Ia diterima melalui jalur SNMPTN di Universitas Riau pada jurusan yang sesuai dengan keinginan hatinya. Sekarang ia sedang menempuh pendidikannya pada semester lima di kampus tercinta.

Kontak:

Hp/Wa: 082385955604

E-mail : aldhanaila0312@gmail.com 